(C) 2014

Писаренко В. П., доктор наук із державного управління

Полтавська державна аграрна академія

\title{
ЗАПРОВАДЖЕННЯ ЕЛЕКТРОННОГО УРЯДУВАННЯ В УКРАЇНІ
}

\section{Рецензент - доктор наук із державного управління, професор Т. М. Лозинська}

\begin{abstract}
Стаття присвячена проблемам запровадження

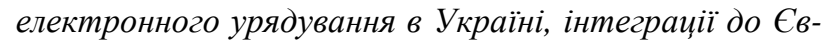
ропейського Союзу та вирішення питання створення свого електронного простору, яке набуває наразі особливої актуальності. У статті проведено аналіз нормативно-правових актів стосовно електронного документування, електронного цифрового підпису, електронного урядування. Наводиться зарубіжний досвід впровадження електронного урядування та доступу населення до інформаційних мереж органів влади і можливості населення у прийнятті важливих рішень для територіальних громад. Сформовано висновки про те, щзо виникнення нових інформаційнокомунікаційних технологій дало підстави говорити про нову телекомунікаційну революцію.
\end{abstract}

Ключові слова: інформачійне суспільство, інформачійно-аналітичні системи, органи публічої влади, інформаційно-комунікаційні технології, електронний уряд.

Постановка проблеми. Інтеграція України до Європейського Союзу та створення інформаційного суспільства вимагає дотримання вимог СС щодо сфери інформаційної політики та безпеки. Для того, щоб увійти у світовий інформаційний простір на рівноправній основі, необхідно удосконалювати взаємовідносини між органами влади і суспільством, вирішити проблеми забезпечення ефективного розвитку національної інформаційної інфраструктури, створення інформаційно-аналітичних систем органів публічої влади, прискорення процесів модернізації програмного й технічного забезпечення, надійного захисту інформаційних ресурсів.

Аналіз останніх досліджень i публікацій, у яких започатковано розв'язання проблеми. Питанням комунікації за допомогою сучасних інформаційних технологій присвячені роботи зарубіжних дослідників, таких як Д. Батлер, Б. Бірельсон, К. Дойч, Д. Істон, П. Лазарсфельд, Н. Негропонте, А. Етціоні; дослідженням інформаційного суспільства займалися 3. Бжезинський, Д. Белл, П. Дракер, М. Маклюен, М. Кастельс, Е. Тоффлер. Питання інформаційного суспільства висвітлені у працях таких відомих учених як Р. Катц, Й. Масуда, М. Порат, Т. Стоуньєр та інші.
Серед українських вчених, які досліджують питання інформаційних технологій, електронного урядування можна відзначити П. Клімушина, Н. Костенко, І. Лопушинського, Ю. Мошкарова, О. Орлова.

Мета дослідження - висвітлити роль інформаційно-комунікаційних технологій (IКТ) у процесі модернізації держави, розглянути ІКТ як один $з$ основних інструментів взаємодії влади i громадянського суспільства.

Завдання полягає у широкому долученні керівників органів публічного управління, спеціалістів і громадськості до найшвидшого проведення відповідних обговорень питання щодо електронного урядування в Україні, передумовою якого повинна бути розробка необхідних нормативноправових документів, підготовки спеціалістів та населення до співпраці в нових умовах інформаційно-комунікаційних технологій.

Результати дослідження. Розуміючи важливість створення інформаційного суспільства, прискорення цього процесу, ще 18 квітня 2002 року на другому засіданні Міжвідомчої комісії 3 питань інформаційної політики та інформаційної безпеки при Раді національної безпеки й оборони України було започатковано довгострокову програму під назвою «Електронна Україна», у рамках якої передбачалися заходи щодо формування відповідної нормативно-правової бази у цій сфері, створення ефективного механізму інформаційної взаємодії органів влади всіх рівнів, впровадження електронного документообігу та забезпечення інформаційної безпеки. Передбачалося створення в Україні такого електронного середовища, в якому кожен громадянин зміг би ефективно здійснювати всі свої звичні взаємини 3 навколишнім світом - контактувати з органами публічної влади, проводити розрахунки, брати участь у голосуванні, тощо.

Ще одним важливим аспектом цієї проблеми $\epsilon$ надання населенню вичерпної інформації про діяльність органів влади (що, безсумнівно, сприятиме зростанню довіри до них) і можливості надійного зворотного зв'язку, що дасть змогу громадянам не тільки одержувати достовірну інформацію про роботу урядових структур, а й 


\section{EKOHOMIKA}

надавати їм власну інформацію. Це підвищить обсяг соціального капіталу в тій формі, яку А. Хиршман назвав «моральними ресурсами», тобто ресурсами, обсяги яких у процесі використання не стільки скорочуються, скільки наростають, а вичерпуються лише в тому випадку, коли ними не користуються. Таким чином, громадяни і влада мають можливість більше довідатися про діяльність і проблеми одне одного [1].

3 огляду на важливість інтеграції України до Європейського Союзу, питання створення свого електронного простору набуває особливої актуальності. Так, створення «електронного уряду» дасть можливість державі значно ефективніше взаємодіяти з громадянами. У науковій літературі під «електронним урядом» розуміється перенесення діяльності уряду в IKT, тобто організація керування державою і взаємодії з громадянами через інформаційні мережі.

«Електронний уряд» дасть змогу ефективніше вести управління, боротьбу з корупцією, створить умови для ефективного розвитку бізнесу, поліпшення інвестиційного клімату, а відтак, стане передумовою для динамічнішого зростання економіки.

Український уряд уже зробив певні кроки на цьому шляху, зокрема, прийнято Закон України «Про Національну програму інформатизації» від 4.02.1998 р. № 74 [2], видано Указ Президента України «Про заходи щодо розвитку національної складової глобальної інформаційної мережі Інтернет та забезпечення широкого доступу до цієї мережі в Україні» від 31.07. 2000 р. № 928 [3], постанови Кабінету Міністрів України «Про Порядок оприлюднення у мережі Інтернет інформації про діяльність органів виконавчої влади» від 4.01.2002 p. № 3 [4] та «Про заходи щодо створення електронної інформаційної системи «Електронний уряд» від 24.02.2003 p. № 208 [5], Закони України від 22.05.2003 p. № 851-IV «Про електронні документи та електронний документообіг» [6] та «Про електронний цифровий підпис» від 22.05.2003 р. № 852-IV [7], «Про Основні засади розвитку інформаційного суспільства в Україні на 2007-2015 роки» від 09.01.2007 p. № 537-V [8], розпорядження Кабінету Міністрів України «Про схвалення Концепції розвитку електронного урядування в Україні» від 13.12.2010 р. № 2250-р [9].

Прийнято також постанову про розробку єдиного Web-порталу Кабінету Міністрів, на якому розміщуватиметься інформація про діяльність органів виконавчої влади. Стратегічно Webпортал визначається не як єдина база даних, а як єдина пошукова система державних органів. Знаючи одну Інтернет-адресу, єдиний телефонний номер, кожен громадянин зможе знайти будь-яку інформацію, що його цікавить.

Фахівці відзначають, що вимагає перегляду парадигма державного управління. Існує ціла низка урядів - центральні, регіональні, галузеві, - які повинні забезпечити функціональну та інформаційну взаємодію з усіма громадянами.

Традиційно виділяють три рівні електронного управління:

- електронне інформування громадян державними органами, коли влада стає більш відкритою для громадян і в електронній інформаційній мережі з'являються вільний доступ до документів, які вона ухвалює, роз'яснюються прийняті рішення;

- електронна взаємодія громадян і державних органів, яку забезпечують механізми спілкування громадян і представників влади у віртуальному просторі в реальному часі щодо обговорення пропонованих i прийнятих рішень, з'ясування тих чи інших питань;

- електронне обслуговування громадян державними органами, яке може здійснюватися установами, уповноваженими на це державним органом (у тому числі й на комерційній основі), щодо одержання тих чи інших документів за електронними запитами, подання електронних податкових декларацій, електронної реєстрації тих чи інших правових актів.

Не можна не відзначити й неабиякий економічний ефект від створення «Електронного уряду». Досвід розвинутих країн світу доводить, що електронна взаємодія громадян $з$ органами влади може коштувати вдвічі дешевше, ніж та, що здійснюється за допомогою реального офісу.

У рамках створення систем інформаційного забезпечення діяльності органів публічної влади розроблено концепції, здійснюються окремі робочі проекти, впроваджуються Закон України «Про Національну систему конфіденційного 3в’язку» [10], документи 3 питань криптографічного захисту інформації. Нині в інформаційній сфері України застосовується близько 90 нормативно-правових актів.

Водночас аналіз змісту сайтів органів влади свідчить, що вони не повністю відповідають вимогам інформативності, інтерактивності й можливості здійснювати трансакції.

Як показує досвід західних держав, найбілыший інтерес для населення становлять електронні сторінки не центральних, а місцевих органів влади. Соціологічні дані свідчать, що для 55 \% грома- 


\section{EKOHOMIKA}

дян необхідна інформація місцевого рівня, $20 \%$ звертань можна вирішити на рівні району чи області й лише $25 \%$ питань стосуються діяльності міністерств і відомств.

«Електронний уряд» $є$ вищою стадією розвитку уряду в умовах інформаційного суспільства. Найкращих результатів із цього питання досягнуто в Канаді, Сінгапурі, США. 3 певним відривом ідуть Австралія, Данія, Велика Британія, Фінляндія, Гонконг, Німеччина, Ірландія, Нідерланди, Франція і Норвегія.

Передбачається, що у майбутньому «Електронний уряд» стане звичним урядом. Наприклад, у США та Західній Європі впровадження нових форм урядування обумовлюється потребою в прозорій і підконтрольній громадянському суспільству діяльності органів влади. Суттю електронної форми урядування $\epsilon$ об'єднання за допомогою інтернет-технологій усіх міністерств і відомств у єдиний комплекс із вищим ступенем інтегрування внутрішніх процесів (документообіг) і єдиним інтерфейсом (вікном взаємодії) 3 громадянином (користувачем). Таким чином, останній одержить можливість спілкуватися не 3 цілою низкою відомств, а 3 одним електронним посередником, що репрезентує їх усіх водночас.

Важливою перевагою електронного урядування $є$ можливість участі населення в обговоренні законопроектів та урядових рішень, які дотепер було для більшості неможливим; свої інтереси зможуть захищати не тільки ті діячі, які мають лобістів, але й решта громадян, які під час обговорення важливого законопроекту чи постанови уряду зможуть висловити власну думку.

В Україні до поняття «Електронна Україна» передусім відносять органи влади, тоді як у західних країнах на першому плані - посилення контролю громадян над урядом, для чого вводяться публічні оціночні показники його діяльності. В Україні таких програм ще немає. Сенс «електронного уряду» - це оновлювана інформація органів влади, що має бути доступною для всіх. Тільки держава може вирішити завдання створення в онлайн режимі нових механізмів, які оптимізують спілкування громадян із бюрократичними інстанціями. Зокрема, варто надати населенню необхідну для особистого користування інформацію (розподіл функцій між підрозділами, години прийому, список необхідних документів, бланки заяв, анкет і т. д.).

Можливі й кардинальніші зміни системи відносин між державним апаратом і громадянами. Мається на увазі реалізація принципу «єдиного вікна», суть якого полягає в тому, що рух інфор- мації між різними відомствами відбувається не за допомогою довідок, які людина одержує в одній інстанції й несе в іншу, а через створення загальної бази даних. Такий механізм прискорить розгляд, наприклад, запиту громадянина, поскільки відповідний державний орган зможе сам терміново зібрати всю необхідну інформацію.

Варто мати на увазі, що власне створення єдиних інформаційних систем ще не змінює відносин органів влади і громадян: для цього необхідна і воля керівників, їхня готовність використовувати можливості, що відкриваються, не тільки для власних цілей, але й для зручності людей.

Однак і тут є труднощі: щоб відкрити таку електронну приймальню, комп'ютера не досить. Необхідні фахівці, які обслуговуватимуть комп'ютерну техніку, консультуватимуть громадян. Таким чином, і в цьому випадку контакт громадян 3 «електронним урядом» без посередників не стане ефективним. Не будемо говорити вже про додаткові фінансові витрати й імовірність черг в електронних приймальнях. Досвід інших країн свідчить, що там проблема «digital divide» вирішується за допомогою вже існуючої мережі комп'ютерних кафе і клубів. До того ж такі клуби на Заході досить популярні, незважаючи на високий рівень інтернетизації. У США, наприклад, за останні два роки кількість таких клубів зросла вдесятеро. Уряди Великої Британії, Швеції й інших розвинених європейських держав реалізують спеціальні програми з розвитку інтернет-кафе для забезпечення масового доступу населення до інформаційних мереж. В Україні нині діє близько 3,5 тисяч комп'ютерних клубів, - на їх основі й можна створити систему електронних приймалень.

Комунікаційна революція створила можливість електронного контролю за життям, напрямами думок, планами й настроями як окремих громадян, так і будь-яких громадських організацій. Централізована обробка й узагальнення інформації дають владі могутній засіб запобігання небажаних дій, опосередкованого управління поведінкою людей. Широкі, майже необмежені, можливості сучасних комп'ютерних технологій щодо обміну, об'єднання і класифікації інформації дають змогу, не докладаючи значних зусиль, створити «інформаційний портрет» індивіда, що дасть можливість державним і приватним інститутам використовувати отриману інформацію у широких інтересах. Ця обставина впливає на самосвідомість громадян, викликаючи відчуття перебування під пильною увагою певних 


\section{EKOHOMIKA}

структур. Науковці відзначають, що вплив інформаційних потоків на світосприймання людини, їі самоідентифікацію робить контроль над нею могутньою і небезпечною зброєю. Крайній щабель такого контролю - монополізація інформаційних каналів - дає монополістові необмежену владу над суспільством.

Окрім цього, населення допоки ще не готове жити в «електронній Україні». На сьогодні близько 30 \% нашого населення має комп'ютерну техніку і $€$ користувачами Інтернету, певна кількість (переважно люди похилого віку) ставиться до цього негативно. Варто враховувати й низьку купівельну спроможність українських громадян, яка не дає змоги на інформаційні технологіі.

У науковій літературі нерідко зустрічається думка, що Інтернет - як інструмент докорінної модернізації громадських і державних структур - забезпечить можливість «новим демократіям» зробити прорив у процесі модернізації суспільства. Порівняння економічних показників різних країн світу, що розвивають інформаційні технології, показує, що хоча диспропорція між ними зберігається, вона незначна у порівнянні з іншими сферами. В Індії, наприклад, експортний оборот програмних продуктів у 2010 році можна порівняти з експортом російської нафти [11].

В українських інформаційних мережах, як відомо, структура мережних систем ще зовсім не відповідає структурі суспільства. Особливості їі такі:

- мінімальна присутність у мережі держави;

- високий ступінь маргіналізації мережі;

- більшість аудиторії - молодь;

- сприйняття Інтернету як царини дій без правил регулювання й дотримання етики;

- панування «рухливого суспільного договору» як основи відносин [12].

3 викладеного можна дійти висновків про те, що: 1. Поява нових інформаційно-комунікаційних технологій дала підстави вести мову про нову інформаційну (телекомунікаційну) революцію, сутністю якої стала заміна однобічного зв'язку між відправником інформації та їі адресатом на багатофункціональний i діалоговий зв'язок із новими, високими можливостями інформаційного обміну. Нові технології дозволяють здійсню-

\section{БІБЛІОГРАФІЯ}

1. Див.: State of Internet. 2000. - http://usic. Wsiogic.com/section1.Pdf.

2. Землянова Л. М. Зарубежная коммуникативистика в преддверии информационного общества. - М., 1999. - С. 56.

3. Про заходи щодо створення електронної ін- вати моніторинг громадської думки, проводити референдуми з оперативним підбиттям підсумків.

2. Зважаючи на те, що прийняті владою рішення на різних рівнях безпосередньо торкаються життєво важливих інтересів суспільства і покликані забезпечувати його стійкий розвиток, суспільство вкрай зацікавлене у всебічному, кваліфікованому і зрозумілому для всіх висвітленні основних питань, пов'язаних із підготовкою й прийняттям рішень. Актуальність цієї проблеми загострилася нині тому, що людство дійшло висновку: світ, у якому воно живе, складний i неоднозначний, а некомпетентність або безвідповідальність влади занадто часто обумовлює прийняття рішень із непередбачуваними наслідками, після чого порушується стійкість розвитку, виникають конфліктні ситуації.

3. Вихід із такої ситуації вбачається у забезпеченні прав громадян на вільний доступ до інформаціï, в їі структуруванні. За дотримання цих умов та використанні сучасних інформаційних технологій (локальні й глобальні комп'ютерні мережі) кожен громадянин одержує можливість переконатися в правильності пропонованих заходів чи не погодитися 3 ними і вільно висловити щодо цього свою думку.

4. Таке трактування права на інформацію істотно розширює можливості впливу широкого кола громадян на прийняття рішень, що ще й тепер продукуються вузьким колом неконтрольованих фахівців і політиків. Таким чином, стає можливим черговий крок на шляху до демократизації, інтелектуалізації, інформатизації суспільства, що сприятиме його стійкому розвитку.

5. Однак стверджувати, що Інтернет вносить принципові зміни в діяльність демократичних інститутів чи демократично обраних лідерів, ще передчасно. Розвиткові системи «електронного уряду» на перешкоді такі причини, як недостатній рівень комп'ютеризації країни, недосконалість законодавчої бази, недостатнє фінансування процесу інформатизації, консерватизм і бюрократизм чиновників. Внаслідок цього влада не може ні поширювати інформацію про свою діяльність у необхідних обсягах, ні ефективно координувати роботу структурних підрозділів.

формаційної системи «Електронний уряд» : Постанова Кабінету Міністрів України від 24 лютого 2003 року № 208 // Офіційний вісник України від 14.03.2003 2003 р. - № 9. - С. 112. - Ст. 378, код акту 24544/2003.

4. Про електронні документи та електронний 
документообіг : Закон України від 22 травня 2003 року № 851-IV // Відомості Верховної Ради України від 05.09.2003 р. - № 36. - Ст. 275.

5. Про електронний цифровий підпис : Закон України від 22 травня 2003 року № 852-IV // Biдомості Верховної Ради України. - 2003. - № 36. - C. 276.

6. Про Національну програму інформатизації : Закон України від 4 лютого 1998 року № 74/98ВР // Відомості Верховної Ради України. - 1998. - № 27-28. - Ст. 181.

7. Про Національну систему конфіденційного зв'язку : Закон України від 10 січня 2002 року № 2919-III // Відомості Верховної Ради України). - 2002. - № 15. - Ст. 103.

8. Про Основні засади розвитку інформаційного суспільства в Україні на 2007-2015 роки : Закон України від 09.01.2007 № 537-V // Відомості Верховної Ради України. - 2007. - № 12. -
Ст. 102.

9. Про Порядок оприлюднення у мережі Інтернет інформації про діяльність органів виконавчої влади : Постанова Кабінету Міністрів України від 4 січня 2002 р. № 3 // Офіційний вісник України від 25.01.2002 р. - № 2. - С. 234. Ст. 57, код акту 21071/2002.

10. Про схвалення Концепції розвитку електронного урядування в Україні : Розпорядження Кабінету Міністрів України від 13 грудня 2010 р. № 2250-p // Офіційний вісник України від 27.12.2010 p. - № 97. - С. 48. - Ст. 3443, код акту $53988 / 2010$.

11. Чугунов A. В. Политика и интернет: политическая коммуникация в условиях развития современных информационных технологий. Автореферат дис. ... канд. полит. наук. С.-Петербург, 2000. - С. 13. 